TINJAUAN PUSTAKA

\title{
Preoksigenasi pada Anestesi Umum
}

\section{Preoxygenation in General Anesthesia}

\author{
Faizal Rahmat Malawat ${ }^{{ }^{*}}$, Bondan Irtani Cahyadi ${ }^{*}$ \\ *Bagian Anestesi dan Terapi Intensif, Fakultas Kedokteran, Universitas Diponegoro/ RSUP Dr. Kariadi, Semarang \\ ${ }^{\triangle}$ Corespondence/ Korespondensi : faizalmalawat@gmail.com
}

\begin{abstract}
Background: Monitoring of hemoglobin saturation during management of airway is important for patients. Desaturation below $70 \%$ can lead patient to dysrhythmic, hemodynamic decompensation, brain damage due to hypoxia and death. The challenge for emergency doctor is to perform agile and swift endotracheal intubation to patients without getting hypoxia or aspiration. Preoxygenation with $100 \%$ oxygen before induction of anesthesia is an extensive maneuver that can increase the body's oxygen storage, adjourning the onset of desaturation during apnea period after induction of anesthesia and musclerelaxants.
\end{abstract}

Objective: The purpose of preoxygenation is to replace nitrogen in FRC with oxygen; which is called the denitrogenation. This has an impact on the body's oxygen storage and increases tolerance for substantial apnea. Effective preoxygenation produces safe limits for emergency intubation and prolongation of apnea duration without getting desaturation.

Method: Preoxygenation in the operating room uses a circuit attached to theanesthesia machine, which will provide high FiO2. Then, the success of preoxygenation can be evaluated by estimating denitrogenation level using gas analyzer to determine the concentration of exhaled oxygen fraction ( $\mathrm{FeO} 2$ ). For the operation of patients with high risk aspiration, anesthesia develops induction with quick sequences by giving sedative and paralytic without ventilation simultaneously while waiting the paralytic effects which can help to reduce aspiration risk. The supine position is not ideal for achieving optimal preoxygenation because it becomes more difficult to breathe and the posterior lungs become susceptible to collapse. On the contrary, Trendelenburg position will increase preoxygenation and may be beneficial in immobilized patients due to possible spinal cord injury.

Conclusion: In apnea condition, the factor that have the greatest effect in hypoxia are $F R C$, alveoli's oxygen concentration, and metabolic rate. The hemoglobin concentration and the circulation shunting level are less important factors. Anesthesiologists can avoid

Volume X, Nomor 2, Tahun 2018 
hypoxia with preoxygenation. Until definitive control of the airway can be reached, anesthesiologists can provide 100\% oxygen which allows the entry of oxygen into the lungs and helps prevent hypoxia.

Keywords: anesthesia; desaturation; hypoxia; preoxygenation; shunting

\section{ABSTRAK}

Latar Belakang: Pemantauan saturasi hemoglobin selama tatalaksana jalan napas penting untuk keselamatan pasien. Desaturasi di bawah 70\% menghantarkan pasien pada risiko mengalami disritmia, dekompensasi hemodinamik, kerusakan otak akibat hipoksia dan kematian. Tantangan untuk dokter emergensi adalah dapat melakukan intubasi endotrakeal secara cepat tanpa hipoksia atau aspirasi. Preoksigenasi dengan $100 \%$ oksigen sebelum induksi anestesi, merupakan manuver yang diterima secara luas yang dapat meningkatkan penyimpanan oksigen tubuh, sehingga menunda onset desaturasi selama periode apnea setelah induksi anestesi dan musclerelaksan.

Tujuan: Tujuan preoksigenasi adalah mengganti nitrogen di FRC dengan oksigen; yang disebut proses denitrogenasi. Hal ini memiliki dampak pada penyimpanan oksigen tubuh dan meningkatkan toleransi terhadap apneu secara substansial. Preoksigenasi efektif menghasilkan batas aman untuk intubasi darurat dan memperpanjang durasi dari apnea tanpadesaturasi.

Metode: Preoksigenasi di dalam kamar operasi biasanya menggunakan sirkuit yang terpasang pada mesin anestesi, yang akan memberikan $\mathrm{FiO}_{2}$ yang tinggi. Kemudian, keberhasilan dari preoksigenasi dapat terus dinilai dengan memperkirakan derajat denitrogenasi menggunakan penganalisa gas untuk menentukan konsentrasi fraksi oksigen yang dihembuskan $\left(\mathrm{FeO}_{2}\right)$. Untuk operasi pasien dengan risiko aspirasi yang tinggi, anestesi mengembangkan induksi dengan sekuens cepat dengan cara pemberian sedatif dan paralitik tanpa ventilasi secara simultan sembari menunggu paralitik berefek, sehingga dapat mengurangi risiko aspirasi. Posisi supine tidak ideal untuk mencapai preoksigenasi optimal, karena menjadi lebih sulit untuk mengambil napas penuh dan lebih banyak bagian paru posterior yang menjadi prone sampai kolaps. Sebaliknya posisi trendelenburg akan meningkatkan preoksigenasi dan mungkin berguna pada pasien yang diimobilisasi karena kemungkinan spinalinjury.

Simpulan: Dalam keadaan apneu, faktor yang memiliki efek terbesar pada waktu tercapainya hipoksia kritis adalah FRC, konsentrasi oksigen alveoli, dan kecepatan metabolisme. Konsentrasi hemoglobin dan derajat pirau sirkulasi kurang penting dibandingkan faktor-faktor diatas. Ahli anestesi dapat menghindari hipoksia dengan preoksigenasi. Sampai kontrol definitif jalan napas dapat dicapai, ahli anestesi dapat memberikan oksigen 100\% sehingga memungkinkan masuknya oksigen ke paru dan membantu mencegah terjadinya hipoksia.

Kata kunci: anestesi; desaturasi; hipoksia; pirau; preoksigenasi 


\section{PENDAHULUAN}

Memantau saturasi hemoglobin selama tatalaksana jalan napas penting untuk keselamatan pasien. Desaturasi di bawah $70 \%$ menghantarkan pasien pada risiko mengalami disritmia, dekompensasi hemodinamik, kerusakan otak akibat hipoksia dan kematian. Tantangan untuk dokter emergensi adalah dapat memasang trakea tube(ET) secara cepat tanpa hipoksia atau aspirasi. Pada pasien tanpa kerusakan/patologi pada paru-paru, adekuat hemoglobin, atau kebutuhan metabolik yang rendah dan inisial pulse oksimetri terbaca $100 \%$, risiko minimal untuk mengalami desaturasi setelah preoksigenasi yang adekuat. Sebaliknya, pada pasien sepsis dengan pneumonia multilobus yang telah mengalami hipoksemia (saturasi oksigen $\leq 90 \%$ ) meskipun mendapatkan laju oksigen tinggi $100 \%$, dapat terjadi hipoksia tiba-tiba selama intubasitrakhea. ${ }^{1-4}$

Preoksigenasi memberikan buffer yang aman selama periode hipoventilasi dan apnea. Preoksigenasi memperpanjang durasi dari apnea yang aman, didefinisikan sebagai waktu sampai pasien mencapai tingkat saturasi dari 85 sampai $90 \%$, untuk dapat memasang jalan nafas yang utama. ${ }^{1,2,4}$

Preoksigenasi dengan 100\% oksigen sebelum induksi anestesi, manuver yang diterima secara luas, meningkatkan penyimpanan oksigen tubuh, sehingga menunda onset desaturasi selama periode apnea setelah induksi anestesi dan muscle relaksan. Preoksigenasi diketahui dapat meningkatkan waktu aman apnea pada dewasa yang sehat antara 3-6 menit. Paling sering, untuk preoksigenasi adekuat, pasien membutuhkan untuk bernapas 100\% oksigen selama 3-5 menit atau mencapai 4-8 kapasitas vital pernapasan dalam untuk 30-60 detik berturut-turut. Ketepatan dari preoksigenasi tergantung pada konsentrasi oksigen inspirasi, laju alirannya, konfigurasi sistem pernapasan, dan karakter pasien. ${ }^{1,2,4}$

\section{DEFINISI}

Preoksigenasi merupakan prosedur keamanan yang sederhana, yang dapat memiliki pengaruh signifikan pada saat desaturasi. Selama apneu, saturasi oksigen arteri tetap tinggi hingga hampir semua cadangan oksigen tubuh telah digunakan. Oximetry arteri bukan prediktor yang baik untuk mengetahui ancaman hipoksemia. Ketika hipoksemia berat terjadi, saturasi oksigen arteri menurun dengan cepat, dengan laju mendekati $30 \%$ /min. Meningkatkan fraksi oksigen yang diberikan pada saluran napas dari 90\% hingga 100\% memperpanjang durasi kelangsungan hidup pada pasien apneu dengan jalan napas terbuka. Penting untuk mempertahankan kepatenan jalan napas saat pasien apneu, bahkan jika tidak ada ventilasi yang diberikan. Waktu untuk mencapai hipoksemia kritis untuk pasien apneu yang obesitas dapat diperpanjang oleh preoksigenasi dalam posisi head-up. $5-7$

\section{TUJUAN}

Tujuan preoksigenasi adalah mengganti nitrogen di FRC dengan oksigen; proses ini juga disebut denitrogenasi. Hal ini memiliki dampak pada penyimpanan oksigen tubuh dan meningkatkan toleransi terhadap apneu secara substansial. ${ }^{4,8,9,10}$

Preoksigenasi efektif menghasilkan batas aman untuk intubasi darurat dengan melakukan denitrogenasi kapasitas residual fungsional dari paru-paru, 
memperpanjang durasi dari apnea tanpa desaturasi. Di ruang operasi, sirkuit anestesi digunakan untuk memberikan $\mathrm{FiO}_{2}$ yang tinggi. Bahkan, derajat denitrogenasi dapat diukur dengan mengukur $\mathrm{FeO}_{2}$ (fraksi ekspirasiOksigen) selama preoksigenisasi. Dengan perikiraan konsentrasi karbondiokisa sebesar 5\%, kadar $\mathrm{FeO}_{2} \quad 90 \%$ sesuai dengan perkiraan konsentrasi nitrogen alveolar yaitu 5\%. Hal ini telah menjadi acuan klinis dan batas akhir preoksigenasi komplet. Penilaian kontinyu dari $\mathrm{FeO}_{2}$ juga membantu ahli anestesi untuk mengidentifikasi kejadian saat preoksigenasi suboptimal, mislnya, dengan penempelan masker yang kurang baik, mendorong penyesuaian pada teknik. ${ }^{1,2,11,12,13}$

Di luar lingkungan ruang operasi, dokter mengandalkan periode 3 menit preoksigenasi, yang secara tradisional dengan bernapas lewat sumber yang diduga menghasilkan $\mathrm{FiO}_{2}$ tinggi menggunakan sistem BVM (bag-valvemask) a tau NRM(none rebreather mask).

Robinson dan Ercole menunjukkan kesetaraan $\mathrm{FeO}_{2}$ yang didapatkan dari preoksigenasi dengan BVM dan NRM . Bagaimanapun, sirkuit anestesi pada mesin anestesi lebih baik dibandingkan alat tersebut. Sebaliknya, bahwa preoksigenasi dengan BVM model khusus didapatkan rerata $\mathrm{FeO}_{2}$ yang setara dengan sirkuit anestesi dan lebih baik secara signifikan daripada NRM. Peneliti sebelumnya menemukan bahwa pada pasien yang bernapas spontan, $\mathrm{FiO}_{2}$ disalurkan oleh BVM tanpa katup ekspirasi satu arah lebih rendah secara signifikan dibandingkan dengan yang memiliki katup ekspirasi satu arah. BVM yang digunakan pada penelitian ini memiliki katup ekspirasi yang mencegah terjebaknya udara ruangan. Dapat disimpulkan bahwa penggunaan BVM yang berbeda dan adanya katup ekspirasi berperan pada perbedaan keberhasilan preoksigenasi, seperti yang telah didemonstrasikan para peneliti terdahulu. ${ }^{14}$

Dapat disimpulkan bahwa keberhasilan preoksigenasi tergantung dari kualitas penempelan, yang kemungkinan berdampak buruk dengan menggunakan NK Nasal kanul. Menariknya, Gagnon dkk. mendemonstrasikan berkurangnya keberhasilan preoksigenasi saat mereka dengan sengaja membuat kebocoran menggunakan pipa nasogastric dibawah masker. ${ }^{10,13,14}$

Penambahan katup PEEP pda BVM juga diduga meningkatkan $\mathrm{FeO}_{2}$ sesuai dengan penelitian sebelumnya yang menunjukkan peningkatan preoksigenasi dengan PEEP. Penambahan katup PEEP dengan pegas pada BVM sekali pakai juga dapat mengurangi terjebaknya udara ruang di sekitar katup ekspirasi pada alatalat ini. Peningkatan preoksigenasi dapat diidentifikasi pada pasien dengan penyakit paru yang mendapat bantuan PEEP untuk memperbaiki alveolus dan jalan napaskecil. $^{10,13}$

Sebuah studi pada tahun 1984 ketika oximetri masih awal dikembangkan mengungkapkan betapa cepat hipoksemia terjadi pada individu yang sehat dan bugar 1 menit setelah induksi anestesi saat preoksigenasi tidak dilakukan. Rata-rata $\mathrm{SaO} 2$ sebesar85,5\% 1 menit setelah induksi. Ketika preoksigenasi dilakukan (meskipun hanya sebentar dan tidak sempurna), $\mathrm{SaO} 2$ menjadi $>90 \%$ pada semua individu yang 
diteliti. $^{5}$

Cara mudah untuk menilai efektivitas preoksigenasi adalah mengukur fraksi oksigen end-tidal (FE'O2), yang akan memberi perkiraan fraksi oksigen alveoli (FAO2). Pada orang dewasa dengan FRC dan $\mathrm{VO} 2$ normal , jika FAO2 >0.9 (yaitu setelah pemberian preoksigenasi), paru akan terisi $2000 \mathrm{ml}$ oksigen (sekitar $10 \mathrm{kali}$ $\mathrm{VO} 2)$.
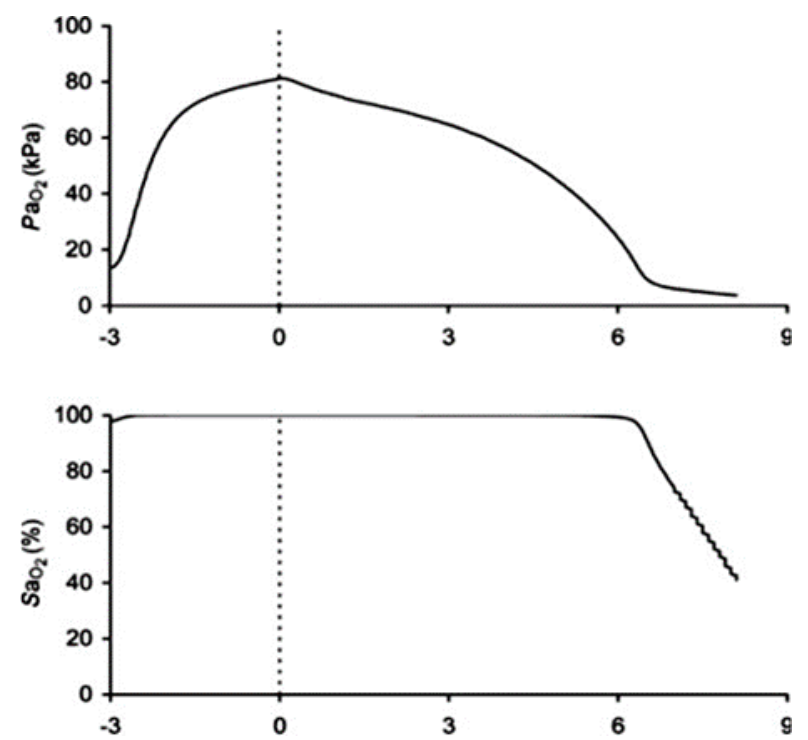

Gambar 1. Simulasi waktu perubahan terhadap tekanan parsial oksigen arteri dan saturasi oksigen hemoglobin arteri pada individu yang sehat yang dilakukan preoksigenasi selama 3 menit dan kemudian mengakibatkan henti napas dengan hambatan jalan napas. Grafik ini dihasilkan oleh simulator FisiologiNottingham

\section{METODE}

Preoksigenasi di dalam kamar operasi biasanya menggunakan sirkuit yang terpasang pada mesin anestesi, yang akan memberikan $\mathrm{FiO}_{2}$ yang tinggi. Kemudian, keberhasilan dari preoksigenasi dapat terus dinilai dengan memperkirakan derajat denitrogenasi menggunakan penganalisa gas untuk menentukan konsentrasi fraksi oksigen yang dihembuskan $\left(\mathrm{FeO}_{2}\right)$.

Jika hal tersebut dibandingkan dengan intubasi darurat yang dilakukan di instalasi gawat darurat (IGD), di unit perawatan intensif (intensive care unit/ ICU), atau tempat sebelum dibawa ke rumah sakit. Intubasi di tempat-tempat tersebut cenderung dilakukan pada pasien tidak terkendali dan pasien dengan gangguan sirkulasi pernapasan. Manajemen saluran napas di IGD dan ICU sudah terbukti berhubungan dengan insiden yang lebih merugikan. Preoksigenasi efektif akan lebih penting dilakukan di tempat tersebut, namun mungkin akan menjadi suboptimal karena beberapa hal. Tidak ada standar 
pelaksanaan preoksigenasi di IGD, ICU, atau tempat sebelum dibawa ke rumah sakit, dan tidak mungkin menilai derajat denitrogenasi sebelum induksi anestesi. $^{8,15,16}$

Metode preoksigenasi yang umum digunakan melibatkan pernapasan tidak dari sumber konsentrasi oksigen tinggi lewat masker selama 3 menit. Sumber $\mathrm{FiO}_{2}$ yang tinggi meliputi: (1) sirkuit anestesi yang mencegah rebreathing $\mathrm{CO}_{2}$; (2) none rebreather mask (NRM); atau (3) alat bag-valve-mask (BVM).

Meski MRN dan BVM keduanya memiliki sistem reservoir yang dapat dilewati gas dengan $\mathrm{FiO}_{2}$ yang tinggi saat dihirup selama puncak aliran inspirasi, keduanya telah terbukti hanya dapat memberikan kenaikan yang tidak terlalu tinggi pada $\mathrm{FeO}_{2}$ ketika diuji. Ini menunjukkan adanya udara yang terjebak disekitar masker dan di sepanjang katup pada alat-alat ini. Penambahan dari katup positive end expiratory pressure (PEEP) di BVM akan mengurangi udara yang terjebak di lubang ekspirasi dari alat BVM, dan penambahan PEEP juga terbukti meningkatkan oksigenasi arterial. Banyak peneliti merekomendasikan penambahan nasal kanul (NK) untuk memfasilitasi oksigenasi selama apnea, dengan proses pergerakan gas yang besar. Pemasangan oksigen NK selama periode preoksigenasi memberikan laju aliran oksigen yang lebih tinggi dan kombinasi dengan BVM dan PEEP dapat memberikan tekanan udara positif terus-menerus, yang telah dibuktikan dapat meningkatkan durasi apnea tanpadesaturasi.

Standar induksi anestesi untuk operasi elektif pasien dilakukan dengan pemberian sedatif, ventilasi, pemberian pelumpuh otot dan meneruskan manual ventilasi sampai pemasangan pipa endotrakeal. Preoksigenasi tidak wajib diberikan pada pasien ini karena ventilasi dilanjutkan pada periode induksi dan karena mereka mempunyai fisiologi yang normal dan kebutuhan metabolik yang rendah.

Untuk operasi pasien dengan risiko aspirasi yang tinggi disebabkan oleh kelainan saluran cerna, atau penyakit kronis, anestesi mengembangkan induksi dengan sekuens cepat. Sebagaimana yang telah dipahami, teknik ini dengan cara pemberian sedatif dan paralitik tanpa ventilasi secara simultan sembari menunggu paralitik berefek, tidak dibutuhkan untuk menghindari hipoksemia. Metode induksi ini telah diadaptasi di IGD, semua pasien yang membutuhkan tatalaksana jalan nafas diasumsikan berisiko untuk terjadi aspirasi, sehingga teknik yang terpilih adalah dengan rapid sequence intubation (RSI). 1,3,12,17

Pada pasien yang akan dilakukan RSI di ruangan dengan $\mathrm{PaO} 2=90$ $100 \mathrm{mmHg}$, desaturasi akan terjadi dalam 45-60 detik antara pemberian sedatif sampai pasien terhubung dengan ventilator. Pada tahun 1950, anestesi menyadari bahwa cara paling aman untuk melakukan RSI dapat dengan mengisi alveolus pasien dengan fraksi oksigen tinggi inspirasi (FiO2) sebelum dilakukan tindakan. Penelitian yang dilakukan oleh Heller dan Watson, dan Heller et al menunjukkan peningkatan waktu desaturasi bila pasien menerima preoksigenasi $100 \%$ oksigen dibandingkan dengan udara ruangan sebelum intubasi trakea. ${ }^{1}$ 


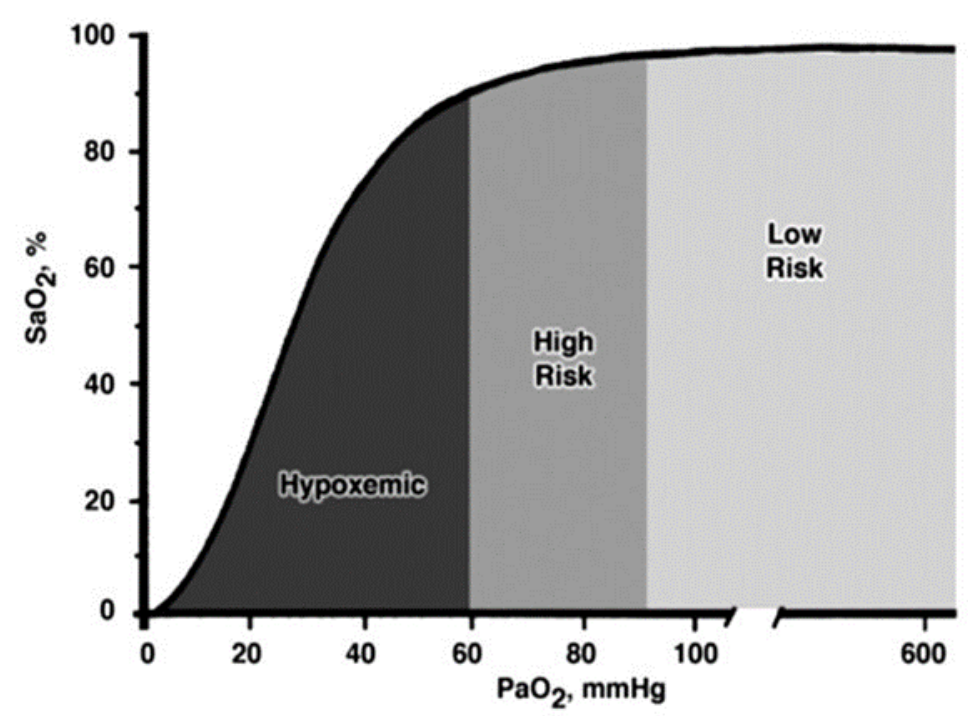

Gambar 2. Kurva disosiasi oksihemoglobin menunjukkan SpO2 dari berbagai level $\mathrm{PaO} 2$. Kategori risiko ditunjukkan pada kurva di atas. Pasien dengan $\mathrm{SpO} 2$ mendekati $90 \%$ memiliki risiko untuk terjadi desaturasi dengan cepat, seperti yang ditunjukkan pada kurva.

Untuk preoksigenasi dari IGD, ada3 tujuan: (1) untuk meningkatkan saturasi pasiens ehingga mendekati $100 \%$; (2) untuk denitrogenasi dari kapasitas residual paru-paru (memaksimalkan penyimpanan oksigen di paru-paru); dan (3) untuk denitrogenasi dan memaksimalkan oksigen di aliran darah. Dua tujuan awal sangat penting; denitrogenasi dan oksigenasi darah menambah sedikit durasi apnea yang aman karena oksigen tidak diserap di darah, dan mempertahankan perbandingan reservoir oksigen antara aliran darah kapiler dengan paru-paru (5\% vs95\%).

Secara ideal pasien harus terus mendapatkan preoksigenasi sampai kapasitas residu fungsional paru-paru mencukupi untuk mencapai lebih dari 90\% tingkat end tidaloxygen .

Pasien yang kooperatif, dapat diminta untuk mengambil 8x napas vital capacity(maksimal ekshalasi diikuti dengan maksimal inhalasi). Metode ini secara umum dapat menurunkan waktu preoksigenasi kurang dari 1 menit. Namun faktanya, banyak pasien di IGD tidak dapat mengambil napas vital capacity.

Waktu diatas diukurpada sumber FiO2 lebih besar atau sama dengan 90\% dan sungkup yang terikat kuat dapat menghindari kebocoranpada udara ruangan. Rekomendasi : pasien dengan respirasi adekuat dapat menerima preoksigenasi selama 3 menit atau mengambil $8 \mathrm{x}$ pernapasan, dengan maksimal inhalasi danekshalasi.

Posisi supine tidak ideal untuk mencapai preoksigenasi yang optimal. Ketika seseorang tidur dengan posisi mendatar, lebih sulit untuk mengambil napas penuh dan lebih banyak bagian paru posterior yang menjadi prone sampai kolaps dan terjadi atelektasis, yang dapat mengurangi reservoir dari 
kandungan oksigen di dalam paru.

Lane et al melaporkan secara acak dan terkontrol dari preoksigenasi pasien posisi head-up 20 derajat versus kelompok kontrol pasien dengan posisi supine. Setelah 3 menit preoksigenasi, pasien menerima sedasi, pelumpuh otot dan kemudian diikuti penurunan saturasi dari 100\% menjadi 95\%. Kelompok head -up membutuhkan waktu 386 detik untuk mencapai saturasi tersebut dan pada pasien posisi supine memerlukan waktu 283 detik. Saat ini, Ramkumar et al mengkonfirmasi hasil ini, dalam kelompok head up 20 derajat membutuhkan waktu 452 detik untuk desaturasi dan 364 detik untuk kelompok supine. ${ }^{14-20}$

Altermatt et al memeriksa secara spesifik preoksigenasi pada pasien obesitas (bmi >35). Penelitian secara acak dan terkontrol membandingkan waktu apnea yang aman pada pasien terintubasi yang menerima preoksigenasi dalam posisi duduk dibandingkan dengan yang menerima preoksigenasi dalam posisi berbaring datar. Setelah dilakukan RSI, trakea terintubasi, pasien apnea dan tidak terhubung denganaliran gas anestesia sampai level $\mathrm{SpO} 2$ menurun dari $100 \%$ menjadi $90 \%$. Pasien yang dilakukan preoksigenasi dalam posisi duduk membutuhkan waktu 214 detik untuk desaturasi dibandingkan pasien yang dipreoksigenasi dalam posisi berbaring membutuhkan waktu 162 detik. Dixon et al menunjukkan manfaat serupa pada 3 randomized controlled trial pada pasien dengan body mass index lebih besar dari 40 yang mana diposisikan pada posisi head up 30 derajat. $^{5,21,22,23,24}$

Sebaliknya posisi Trendelenburg (kepala 30 derajat lebih tinggi dari kaki) juga meningkatkan preoksigenasi dan mungkin berguna pada pasien yang tidak dapat terikat pada bahu, yang diimobilisasi karena kemungkinan spinal injury.

Manfaat tambahan dari posisi kepala lebih tinggi adalah laring dapat terbuka yang lebih baik selama laringoskopi direk.

\section{RINGKASAN}

Jika ventilasi tidak mungkin setelah timbulnya apneu, faktor yang memiliki efek terbesar pada waktu tercapainya hipoksia kritis adalah FRC, konsentrasi oksigen alveoli, dan kecepatan metabolisme. Konsentrasi hemoglobin dan derajat shunting sirkulasi kurang penting dibandingkan faktor-faktor diatas.

Ahli anestesi dapat menghindari hipoksia dengan preoksigenasi. Hingga jalan napas definitif dapat tercapai, ahli anestesi dapat memberikan oksigen $100 \%$ ke jalan napas yang paten sehingga memungkinkan masuknya oksigen secara pasif ke paru dan membantu mencegah terjadinya tekanan intratorakal sub atmosferik.

\section{DAFTAR PUSTAKA}

1. Weingart SD, Levitan RM. Preoxygenation and prevention of desaturation during emergency airway management. Ann Emerg Med.2012;59:165-75.

2. Lauscher P, Mirakaj V, Koenig K, Meier J. Why hyperoxia matters during acute anemia. Minerva Anestesiol 2013;79:643-51.

3. Pelosi P, Ravagnan I, Giurati G, 
Panigada M, Bottino N, Tredici S et al. Positive end-expiratory pressure improves respiratory function in obese but not in normal subjects during anesthesia and paralysis. Anesthesiology 1999;91:1221- 31

4. Edmark L, Auner U, Enlund M, Ostberg E, Hedenstierna G. Oxygen concentration and characteristics of progressive atelectasis formation during anaesthesia. Acta Anaesthesiol Scand 2011;55:75-81.

5. Lumb AB. Nunn's Applied Respiratory Physiology.7th ed. Churchill Livingstone; Oxford 2010:568

6. Campbell IT, Beatty PC. Monitoring preoxygenation. $\mathrm{Br} \mathrm{J}$ Anaesth 1994;72:3-4.

7. Morrison JE, Jr., Collier E, Friesen RH, Logan L. Preoxygenation before laryngoscopy in children: how long is enough? Paediatr Anaesth 1998;8:293-8.

8. Baillard C, Depret F, Levy V, Boubaya M3, Beloucif S. et al. Incidence and prediction of inadequate preoxygenation before induction of anaesthesia. Ann Fr Anesth Reanim 2014;33:e55-e58

9. Baillard C, Depret F, Levy V, Boubaya M3, Beloucif S. et al. Incidence and prediction of inadequate preoxygenation before induction of anaesthesia. Ann Fr Anesth Reanim 2014;33:e55-e58

10. Fraioli RL, Sheffer LA, Steffenson JL. Pulmonary and cardiovascular effects of apneic oxygenation in man. Anesthesiology 1973;39:58896.
11. Cheney FW, Posner KI, LeeLA Caplan RA. Domino KB. Trends in Anesthesia related death and brain damage : a closed claims analysis, Anesthesiology 2006; 105; 1081-6

12. Jense HG, Dubin SA, Silverstein PI, O'Leary-Escolas U. Effect of obesity on safe duration of apnea in anesthetized humans. Anesth Analg 1991;72:89-93

13. Delay JM, Sebbane M, Jung B, Nocca D, Verzilli D, Pouzeratte Y et al. The effectiveness of noninvasive positive pressure ventilation to enhance preoxygenation in morbidly obese patients: a randomized controlled study. Anesth Analg 2008;107:1707-13

14. Nimmagada U, Salem MR, Joseph $\mathrm{NJ}$, et al. Efficacyof preoxygenation using tidal volume and deep breathing techniques with and without priormaximal exhalation.Can JAnaesth.2007;54:448---52.

15. Lee YS. Effects of propofol target-controlled infusion on haemodynamic and respiratory changes with regard to safety. J Int Med Res 2004;32:19-24

16. Gambee AM, Hertzka RE, Fisher DM. Preoxygenation techniques: comparison of three minutes and four breaths. Anesth Analg 1987;66:468-70.

17. McGowan P, Skinner A. Preoxygenation--the importance of a good face mask seal. $\mathrm{Br} \mathrm{J}$ Anaesth 1995;75:777-8.

18. Campbell IT, Beatty PC. Monitoring preoxygenation. $\mathrm{Br} \mathrm{J}$ Anesth1994;72;3-4

19. Rassam S, Stacey M,Morris S. 
How do youpreoxygenate your patient? Int JObstet Anesth. 2005;14:79.

20. Lee C, Jahr JS, Candiotti KA, Warriner B, Zornow MH, Naguib M. Reversal of profound neuromuscular block by sugammadex administered three minutes after rocuronium: a comparison with spontaneous recovery from succinylcholine. Anesthesiology 2009;110:1020-5.

21. Pelosi P, Ravagnan I, Giurati G, Panigada M, Bottino N, Tredici S et al. Positive end-expiratory pressure improves respiratory function in obese but not in normal subjects during anesthesia and paralysis. Anesthesiology
1999;91:1221- 31.

22. Rooney MJ. Pre-oxygenation: a comparison of two techniques using a Bain system. Anaesthesia 1994;49:629-32.

23. Baraka AS, Taha SK, Aouad MT, El-Khatib MF, Kawkabani NI. Preoxygenation: comparison of maximal breathing and tidal volume breathing techniques. Anesthesiology 1999;91:612-6.

24. Kinouchi K, Fukumitsu K, Tashiro C, Takauchi Y, Ohashi Y, Nishida T. Duration of apnoea in anaesthetized children required for desaturation of haemoglobin to 95\%: comparison of three different breathing gases. Paediatr Anaesth 1995;5:115-9. 